ISSN 2693-2504

\title{
Total Phenols, Identification of Active Compounds and Anticancer Activity of Salvia judaica Boiss against the breast Cancer Cell MDA-231
}

Journal of Bioscience \& Biomedical Engineering

Research Article

\author{
Abeer Saleh" ${ }^{*}$, Georget Babojian², Nizar Issa ${ }^{3}$ and Noama Shareef ${ }^{4}$ \\ ${ }^{1}$ Botany Department, Sciences College, Damascus University, \\ Syria. \\ ${ }^{2}$ Botany Department, Sciences College, Damascus University, \\ Syria. \\ ${ }^{3}$ Zoology Department, Sciences College, Damascus University, \\ Syria. \\ ${ }^{4}$ Environmental Science and Engineering expert at CIM: \\ International Center for Migration and Development, \\ Frankfurt, Germany.
}

\author{
*Correspondence authors \\ Abeer Saleh \\ Botany Department, Sciences College \\ Damascus University \\ Syria
}

Submitted : 19 Aug 2021 ; Published : 8 Oct 2021

\begin{abstract}
Salvia judaica is an annual herb from genus Salvia L.; the largest genera of Lamiaceae. It's a medicinal plant prominent in pharmaceutical applications in many countries around the world.
\end{abstract}

This study aimed to explore bioactive compounds likely to be responsible for the plant anticancer activity, and evaluate anticancer effects, after determining the total content of phenols in the ethanol extract and essential oil in this species.

Ethanol extract (EE) and essential oil (EO) were prepared from dried aerial parts (leaves and the flower).

GC-MS analysis of EO showed the presence of/43/ effective compounds in varying proportions, the major compounds were sesquiterpenes like delta-cadinene, alpha-Gurjunene, beta-humulene, and alpha-caryophyllene.

This is the first study revealed that S.judaica is so rich in phenols which proceeded S.officinalis, noting the superiority of the EE over the EO samples in the total phenols.

Anticancer properties of EE and EO of S. judaica against MDA-231 breast cancer cell line were studied-for the first time - by cell cycle analysis and Annexin V/PI apoptosis assay using Flow cytometry technique. Cells were treated with $E E(0.001,0.01,0.02,0.1 \mathrm{mg} / \mathrm{ml})$ and $E O(0.005,0.01,0.02,0.03,0.04 \mathrm{mg} / \mathrm{ml})$ at various concentrations for 48 $h$.

The results revealed that both EE and EO induced cell cycle arrest at G1-phase.

Cells treated with EE and EO for 48 h showed increasing the percentage of cells in G1-phase and decreasing the percentage of cells in S-phase with increasing concentration compared with untreated cells (control).

Annexin V-FITC/PI assay confirmed that EO and EE were able to induce apoptosis. Cells treated with EOat (0.04 $\mathrm{mg} / \mathrm{ml}$ ) for $48 \mathrm{~h}$ resulted in apoptotic cells at $96.68 \%$, and necrotic cells at $0.12 \%$, compared with untreated cells. On the other hand, Cells treated with EE at $(0.1 \mathrm{mg} / \mathrm{ml})$ for $48 \mathrm{~h}$ resulted in apoptotic cells at $94.43 \%$, and necrotic cells at $0.47 \%$, compared with control.

Results revealed that EO is better than EE as anticancer; treatment with EO resulted in more apoptotic cells and less necrotic cells, and there were significant differences between them. This confirmed that EO contains specific anticancer compounds as showed by GC-MS analysis.

However, more studies should be performed to explore antioxidants present in S.judaica and determine the underlying mechanism of their anti-breast cancer properties.

Keywords: Salvia Judaica, Total Phenols, GC-MS, Breast Cancer, Cellular Cycle, Apoptosis. 


\section{Introduction}

Salvia Judaica boiss is 0ne of salvia L, the bigger genus of Lamiaceae. It includes about 1000 species distributed in large tropical and Mediterranean areas in both the old and new worlds. The West Asia region and the Mediterranean Sea Basin are considered as central distributing Habitats [1]. The Syrian Flora contains 26 species, four of them are endemic, and another four species concluded 6 varieties [2].

Lamiaceae (Labiatae previously) plants have volatile compounds in all their parts. Family naming refers to the lip petal shape in their flowers; each flower contains of partly fused petals, /2/ upper lip, /3/lower lip. The leaves are oval and oblong, perfect or even lobed [3]. The stem is square in cross section which is almost supported by a Colanchem tissue [4]. Many studies focused on the essential oil and the organic extracts biological properties of salvia L. They showed that they have anti-microbes, anti-oxidant, anti-diabetes, anti-tumors, anti-inflammatory and anti-nervous activities [5].

S.judaica produces a lot of effective secondary metabolites including terpenes, phenols and their derivatives, so it was a main part of the folklore medicine all over the world. Many studies revealed that this species contains phenolic acids and flavonoids that have antioxidant activity [6]. They are also used in food industries and cosmetics products [7].

Cancer occurs as a result of disorder in cells growth control mechanisms. Tumors develop because of over growth of cells and inhibition of apoptosis which leads to an imbalance in cells and uncontrolled growth [8].

Cancer cell lines derived from tumors are the most cells used in tumors treatment researches which enhances the understanding of the cancer biology during the last decades [9].

Breast and cervical cancers are the most spreading in women [10]. Estrogen has a main role in their growth, so many treatments were applied to inhibit its effects [11].

The second most spreading cancer in men is prostate cancer, traditional cancer treatments almost effect on the life patients because of their dangerous side effects, so it is necessary to replace these treatments with others safer. The study of published the first report about the inhibiting effect of S.judaica on colon-rectal cancer [12].

The effect of S.judaica on breast cancer cells hasn't been studied yet. The current study aimed to identify bioactive compounds in this plant and study anti-cancer activity on MDA231 breast cancer cell line.

\section{Materials and Methods}

\section{Plant material}

The aerial parts of S.judaica were collected from the following sites in countryside of Lattakia: Slenfah/Al-Jowayz, Al-Qardaha/ Al-Murran) in spring of 2018, 2019 years. They were iden- tified by Prof. Babogian: Botany Department, Science Faculty, and Damascus University, Syria.

\section{Plant extraction}

\section{Ethanol Extract (EE) preparation}

About 50g of powdered dried leaves and flowers were macerated with ethanol $80 \%$ in dark glass containers on the magnetic shaker for $24 \mathrm{~h}$ at $180 \mathrm{rpm}$. The extract was separated from the plant material by centrifugation at $(5300 \mathrm{rpm})$ and filtration. These steps were performed 3 times during 72h. Extracts were added to each other's, then the solvent was evaporated by the rotary evaporator. The dried extracts were stored at $\left(-20^{\circ} \mathrm{c}\right)$. Solvents were purchased from Merck Company.

\section{Essential oil (EO)extraction:}

The EO of S.judaica was prepared from the dried leaves and flowers of this plant (50 g) for 5 hours of hydro distillation using a Clevenger-type apparatus. Powder of a hydrous sodium sulphate was added to obtain the EO without water, then it was stored at $\left(+4^{\circ} \mathrm{c}\right)$.

\section{GC-MS analysis of EO}

GC-MS analysis of the samples was carried out using Agilent series 6890 gas chromatograph with non-polar using column HP-5MS $5 \%$ column $\left(325^{\circ} \mathrm{C}: 30 \mathrm{~m} \times 250 \mu \mathrm{m} \times 0.25 \mu \mathrm{m}\right)$, at a flow rate of $1 \mathrm{~mL} /$ minute.

Helium was used as the carrier gas and the temperature programming was set with initial oven temperature at $50{ }^{\circ} \mathrm{C}$, increased at $50{ }^{\circ} \mathrm{C} / \mathrm{min}$ to $100^{\circ} \mathrm{C}$, and the final temperature of the oven was $280^{\circ} \mathrm{C}$ and held for 1.3719 minutes. $2 \mu \mathrm{l}$ sample was injected with Relative Scan mode, ionization potential 1635 $\mathrm{eV}$ and a scan range of 50-650. The total running time for a sample is $28.5 \mathrm{~min}$. The chemical components from the stem extracts were identified by comparing the retention times of chromatographic peaks with NIST.

\section{Total Phenols Assay}

Total phenolic content of EE and EO was determined by the method of (Al-Hafez, et.al, 2014). Using the Folins-Ciocalteau reagent and gallic acid as standard.A $1 \mathrm{ml}$ of extracts was taken in test tube and then $4.8 \mathrm{ml}$ of distilled water was added to EE ( $4.8 \mathrm{ml}$ of DMSO to EO). $4 \mathrm{ml}$ of $2 \%$ sodium carbonate was added. Folins-Ciocalteau reagent was added to the mixture and shake thoroughly. Mixture was allowed to stand for $1 \mathrm{~h}$. Absorbance was measured at $760 \mathrm{~nm}$. The same procedure was repeated for all different concentrations of gallic acid which prepared in ethanol and a standard curve was obtained. All tests were performed in triplicate. Results were expressed as milligram of gallic acid equivalent per gram of dry extract weight.

Anti-cancer activity of EE and EO against MDA-231 breast cancer cell line

\section{Cell culture}

MDA-231 cells and seeded in a six-well culture plate and grown in a humidified incubator $(95 \%)$ at $37^{\circ} \mathrm{C}$ with $5 \% \mathrm{CO} 2$. 
The cell culture medium was RPMI 1640 supplemented with $10 \% \mathrm{FBS}$ and $1 \%$ penicillin/streptomycin.

All cell culture chemicals were purchased from Sigma-Aldrich.

Cell cycle analysis by flow cytometry.

Cell cycle analysis was performed by PI-based measurements of cell DNA content using flow cytometry. Cells were treated with various concentrations of $\mathrm{EE}(0.001,0.01,0.02,0.1 \mathrm{mg} /$ $\mathrm{ml})$ and EO $(0.005,0.01,0.02,0.03,0.04 \mathrm{mg} / \mathrm{ml})$ (dissolved in DMSO) for $/ 48 / \mathrm{h}$, followed by collection of both attached and detached cells. The pellet was rinsed twice with cold PBS and cells were fixed in $70 \%$ ice-cold ethanol overnight at $20^{\circ} \mathrm{C}$. Fixed cells were then washed twice with PBS, and DNA was stained with PI(Sigma-Aldrich) staining solution $(20 \mu 1$ of cell suspension were added to $2 \mathrm{ml}$ of staining solution) and incubated in the dark for $5 \mathrm{~min}$. Flow cytometry analysis was carried out using BD FACSCalibur Flow Cytometer.

Annexin V/PI apoptosis assay.

Cells were cultured $(1 \times 106$ cells $/ \mathrm{ml})$ overnight in $25 \mathrm{~cm} 2$ cell culture flasks. Then, cells were treated with various concentrations of $\mathrm{EE}(0.001,0.01,0.02,0.1 \mathrm{mg} / \mathrm{ml})$ and $\mathrm{EO}(0.005,0.01$, $0.02,0.03,0.04 \mathrm{mg} / \mathrm{ml}$ ) (dissolved in DMSO) for $/ 48 / \mathrm{h}$. After treatment, both adherent and detached cells were collected and rinsed twice with cold PBS. The cell pellet was resuspended in $1 \mathrm{ml}$ of annexin-binding buffer and incubated with $5 \mu \mathrm{l}$ of Annexin V-FITC and $5 \mu \mathrm{l}$ of PI for $15 \mathrm{~min}$. The cells were analyzed by flow cytometry and data were analyzed through Cell Quest program.

Annexin V-FITC and PI double staining kit were purchased from BD (USA).

\section{Statistical analysis}

Experimental data were presented as the mean $\pm \mathrm{SD}$. Data were analyzed. Using the Student's t-test. $\mathrm{P}<0.05$ was considered statistically significant.

\section{Results and Discussion}

\section{GC-MS analysis}

GC-MS analysis revealed the presence of 43 compounds, $68.382 \%$ of them are sesquiterpenes like beta-humulene $(22.496 \%)$, Germacrene-d (12.450\%), alpha.-Gurjunene (6.098\%), alpha.-Caryophyllen (5.015\%), Caryophyllene oxide $(8.110 \%), \alpha$-Copaene $(3.531 \%), \delta$-Selinene $(2.928 \%)$, Isolongifolene (2.364\%), $\alpha \& \beta$-pinene (1. 521).(Figure,table1)

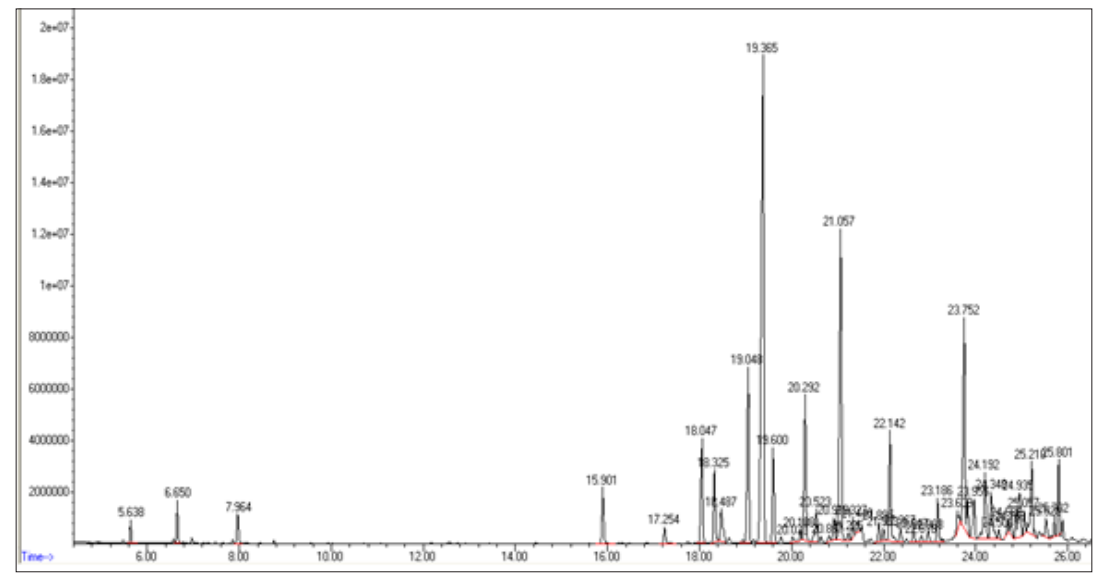

Figure 1: GC-MS analysis chromatogram of EO (the pink arrows refer to high value peaks)

\begin{tabular}{|l|l|l|l|}
\hline No. & COMPOUNDS & Area Pct & RT \\
\hline 1 & $\alpha$-pinene & 0.521 & 5.641 \\
\hline 2 & $\beta$-pinene & 1 & 6.652 \\
\hline 3 & $\alpha$-Cubebene & 0.636 & 17.256 \\
\hline 4 & $\alpha$-Copaene & 3.531 & 18.044 \\
\hline 5 & alpha.-Gurjunene & 6.098 & 19.049 \\
\hline 6 & beta.-humulene & 22.496 & 19.368 \\
\hline 7 & .alpha.-Caryophyllen & 5.015 & 20.291 \\
\hline 8 & Germacrene-d & 12.450 & 21.058 \\
\hline 9 & delta.-Cadinene & 3.869 & 22.144 \\
\hline 10 & Caryophyllene oxide & 8.110 & 23.753 \\
\hline 11 & salvial-4(14)-en-1-one & 1.644 & 23.957 \\
\hline 12 & $\delta$-Selinene & 2.928 & 24.194 \\
\hline 13 & Isolongifolene & 2.364 & 24.350 \\
\hline
\end{tabular}

Table 1: The most important compounds in EO of S.Judaica. 
A previous Jordanian Study about S.judaica revealed the occurrence of sesquiterpenes in EO of dry leaves at $50.8 \%$, and compounds were similar to those in our study, except isolongifolene which was found in our study and absent in the Jordanian Study [12].

The volatile oil composition of S.judaica was studied only by Hungarian researchers who found similarities between the volatile constituents of this species and S.officinalis in terms of presence of $\alpha$-humulene and $\beta$-pinene as the major components of the volatile fraction $[13,14]$.

Total phenols content

According to the oil samples, the total phenols content in $(1 \mathrm{~g}$ of oil) is depending on that every $(100 \mathrm{ml})$ equals $(102.65 \mathrm{mg})$ weigh, (Figure2, table2)

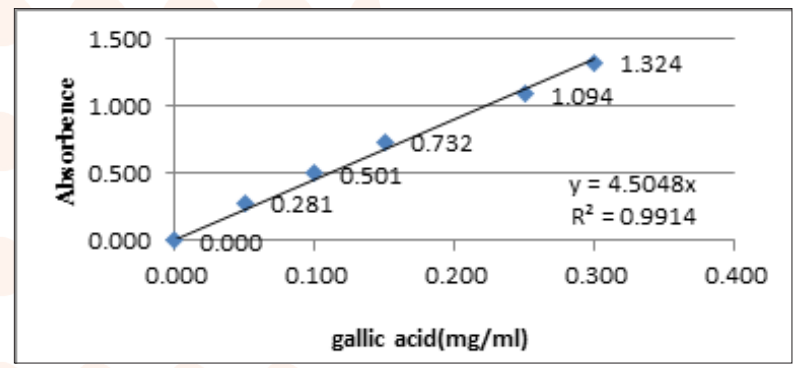

Figure 2: The standard curve of gallic acid

\begin{tabular}{|l|l|}
\hline EE & EO \\
\hline $63.59 \pm 0.63 \mathrm{mg} / \mathrm{g}$ & $102.78 \pm 0.0 \mathrm{mg} / \mathrm{g}$ \\
\hline
\end{tabular}

Table 2: Total phenols content in (EO) and (EE)

(Table2) revealed that EE contained the highest content of phenols comparing with EO $(102.78 \pm 0.0 \mathrm{mg} / \mathrm{g}, 63.59 \pm 0.63 \mathrm{mg}$ $/ \mathrm{g}$ in $\mathrm{EE}$ and $\mathrm{EO}$ respectively).

These results are compatible with the previous study that studied the phenolic content of aerial parts of S.officinalis [15]. This study showed that EE80\% contained $94.35 \pm 1.29 \mathrm{mg}$ gallic acid/g, whereas EO contained $0.708 \pm 0.003 \mathrm{mg}$ gallic acid $/ \mathrm{g}$ dry weight extract.

\section{Anti-cancer activity of EE and EO against MDA-231 breast} cancer cell line

Cytometry cycle analyzing

When analyzing cell cycle using PI staining, cells treated with higher concentration of EO for $48 \mathrm{~h}$ showed higher accumulation of cells at G1 phase compared to untreated cells (control). This was evident in cells treated with the highest concentration of EO $(0.04 \mathrm{mg} / \mathrm{ml})$ which showed increasing the percentage of cells in G1 phase and decreasing the percentage of cells in S phase (74.76\% and $25.24 \%$ respectively). Similarity, cells treated with higher concentration of $\mathrm{EE}(0.1 \mathrm{mg} / \mathrm{ml})$ for $48 \mathrm{~h}$ showed increasing the percentage of cells in G1-phase (78.72\%) and decreasing the percentage of cells in S-phase (14.55\%) by increasing concentration compared with control. Significant differences were found between EO and EE treatment results. (Figure 3, 4).

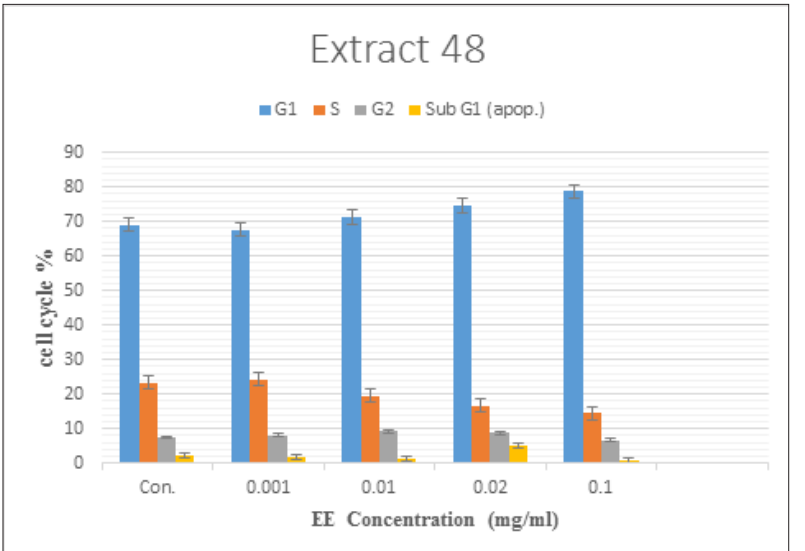

Figure 3: Bar graphs representing cell cycle analysis in cells treated with EE $80 \%$ for $48 / \mathrm{h}$.

Data are represented as mean $\pm \mathrm{SD}(\mathrm{P}<0.05)$

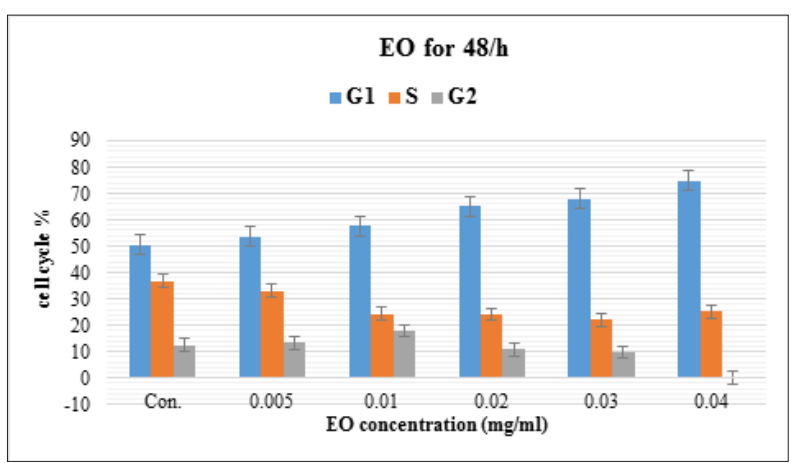

Figure 4: Bar graphs representing cell cycle analysis in cells treated with EO for 48/h.

Data are represented as mean $\pm \mathrm{SD}(\mathrm{P}<0.05)$

Annexin V/PI apoptosis Assay 


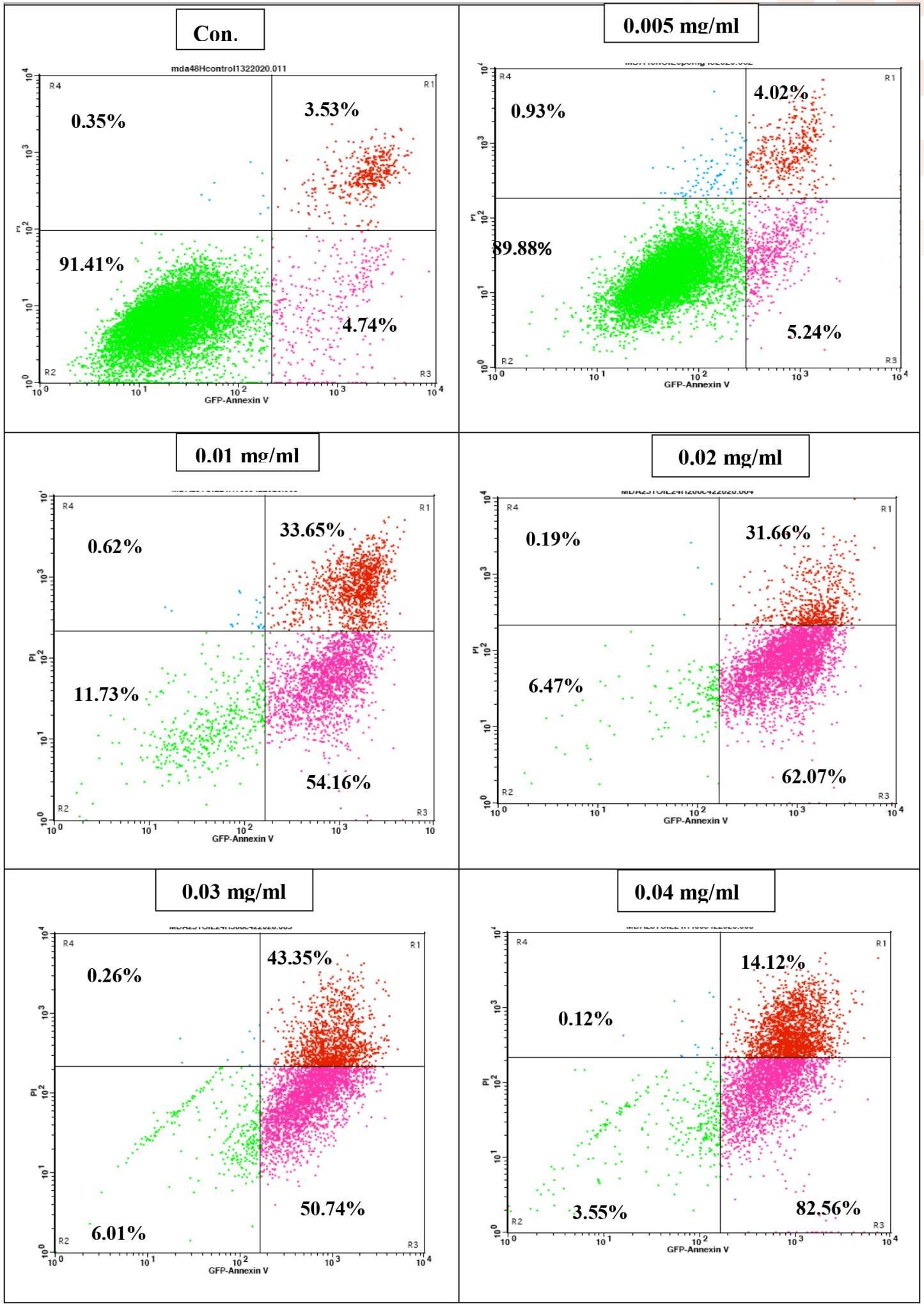

Figure 5: Fraction of viable, apoptotic and necrotic MDA-231 cells treated with different concentrations of EO for 48/h. R1:Dead Cells (Late Apoptotic)، R2:Live Cells‘ R3: Apoptotic، R4:Dead Cells (Necrotic)

A:control cells, B: cells treated with $0.005 \mathrm{mg} / \mathrm{ml}$, C: cells treated with $0.01 \mathrm{mg} / \mathrm{ml}$, D: cells treated with $0.02 \mathrm{mg} / \mathrm{ml}$, E: cells treated with $0.03 \mathrm{mg} / \mathrm{ml}, \mathrm{F}$ : cells treated with $0.04 \mathrm{mg} / \mathrm{ml}$.

Particularly, cells were treated with different concentrations of EO and EE, and the double staining Annexin V-PE / PI allowed to measure the percentage of live, apoptotic and necrotic cells. 


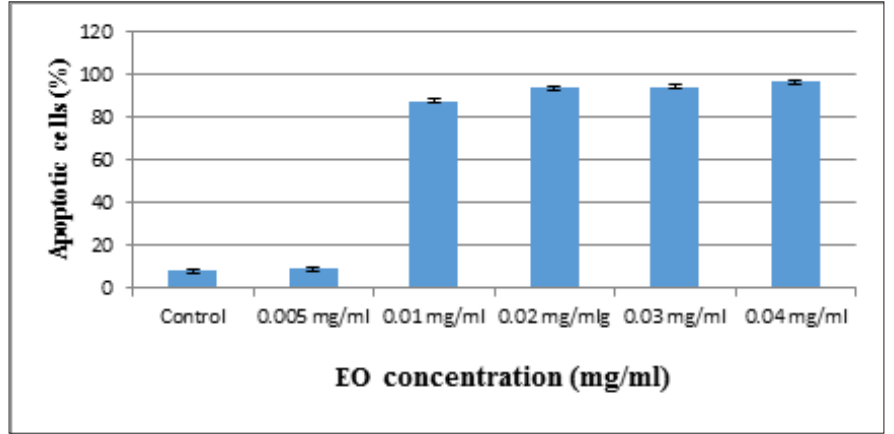

Figure 6: Apoptotic cells treated with EO, Data are represented as mean SD. $\pm(\mathrm{P}<0.05)$

As shown in (Figures 5, 6) cells treated with $0.04 \mathrm{mg} / \mathrm{ml}$ of EO showed increasing of percentage of apoptotic cells $(96.68 \%$ ) and decreasing of percentage of necrotic cells $(0.12 \%)$ as compared to control.

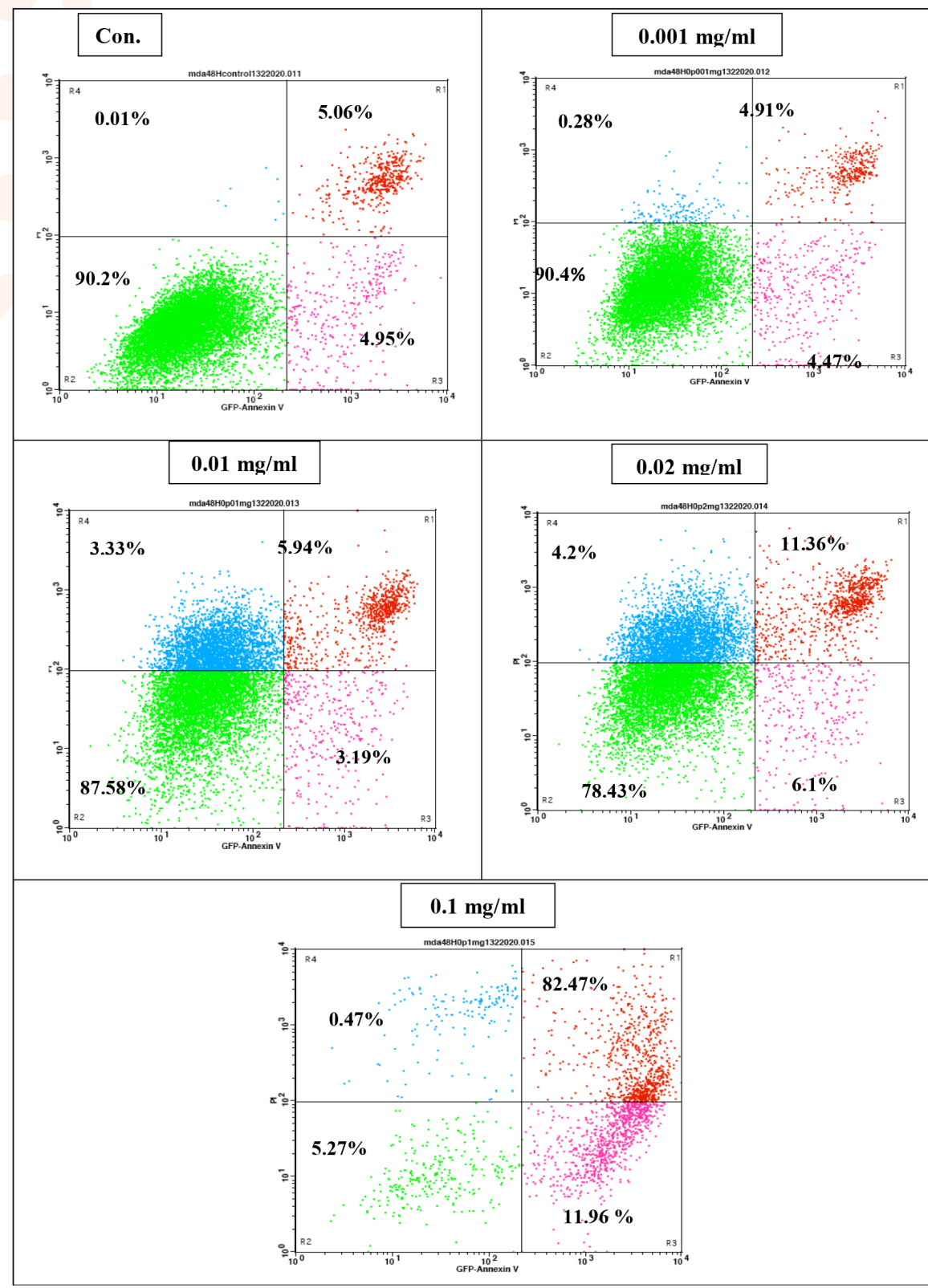

Figure 7: Fraction of viable, apoptotic and necrotic MDA-231 cells treated with different 7concentrations of EE for 48/h.

R1:Dead Cells (Late Apoptotic)، R2:Live Cells‘ R3: Apoptotic، R4:Dead Cells (Necrotic)

A:control cells, B: cells treated with $0.001 \mathrm{mg} / \mathrm{ml}$, C: cells treated with $0.01 \mathrm{mg} / \mathrm{ml}$, D: cells treated with $0.02 \mathrm{mg} / \mathrm{ml}$, E: cells treated with $0.1 \mathrm{mg} / \mathrm{ml}, \mathrm{F}$ : cells treated with $1 \mathrm{mg} / \mathrm{ml}$. 


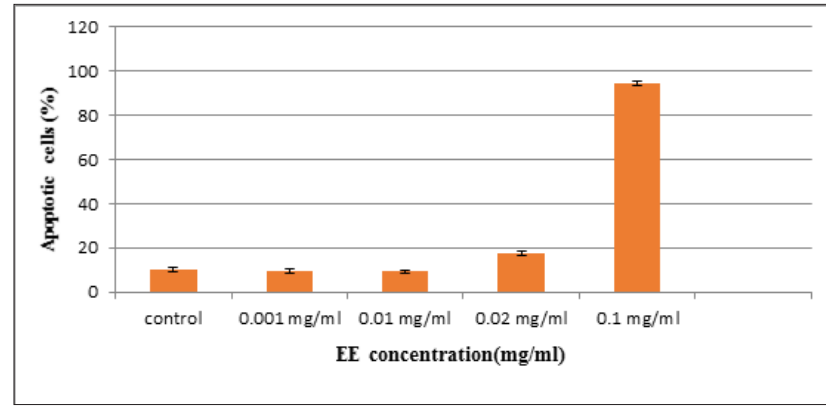

Figure 8: Apoptotic cells treated with EE. Data are represented as mean $\mathrm{SD}(\mathrm{P}<0.05) \pm$

Similar results were obtained when treating cells with relatively higher concentration of $\mathrm{EE}(0.1 \mathrm{mg} / \mathrm{ml}$ ) (Figures 7,8), which means that EE was effective as anti-cancer as previous study showed [16], which confirmed the anti-cancer activity of EE of S.triloba against MCF-7. However, Salvia species are rich in polyphenols including flavonoids and caffeic acid derivatives [17].

Significant differences were found between results of treating cells by EO and EE. These results refer that EO was much better than EE as anti-cancer and it was safer because it caused less necrotic cells.

These results due to that EO contains specific anti-cancer compounds showed by GC-MS analysis, especially caryophyllene, humulene and salvial-4(14)-en-1-one (Fig1, Tab2). Many studies confirmed our results and revealed anti-cancer activity of caryophyllene and humulene against MCF-7 cells [18]. In addition, salvial-4(14)-en-1-one is known to its anticancer effect against many cancer types like human leukemia K-562 and gastric carcinoma SGC-7901 cells [19].

\section{Conclusion}

To our knowledge, S.judaica breast anti-cancer activity hasn't been studied before now. S.judaica EO is rich in bioactive terpens, and its phenolic content outperformed that belong to S.officinalis. Both EO and EE were able to arrest cell cycle in MDA-231breast-cancer cells at G1 phase. They also induced apoptosis in cells treated with them for $48 \mathrm{~h}$, but EO was much better and safer.

However, more studies should be performed to explore anti-oxidants present in S.judaica and determine the underlying mechanism of their anti-breast cancer properties.

\section{Acknowledgements}

This work was supported by Biotechnology Department in Atomic Energy Commission of Syria, Damascus, Syria.

\section{References}

1. Kahraman, A., Celep, F., Dogan, M. (2010) Anatomy, trichome morphology and palynology of Salvia chrysophylla Stapf (Lamiaceae). South African Journal of Botany, 76: 187-195.

2. Mouterde P., 1983- New flora from Lebanon and Syria. Beirut Dar El- Machreq, Tome III, pp: 155-171.

3. Celep, F., Kahraman, A. and Atalay, Z. (2014) Morphology, anatomy, palynology, Mericarp and trichome micro morphology of the rediscovered Turkish endemic Salvia quezelii (Lamiaceae) and their taxonomic implications. Plant Systematics and Evolution.

DOI: 10.1007/s 00606-014-1020-1.

4. Özdemir, A., Özdemir, A. Y. \& Yetisen, K. (2016) Statistical Comparative Petiole Anatomy of Salvia sp. Planta Daninha, 34 (3): 465-474.

5. Chan, H.H., Hwang, T.L., Su, C.R., Reddy, M.V.B., Wu, T.S. (2011) Anti- inflammatory, anticholinesterase and anti-oxidative constituents from the roots and the leaves of Salvia nipponica Miq. Var. formosana Phyto medicine, 18: 148-150.

6. Albayrak, S., Aksoy, A., Albayrak, S., Sagdic, O. (2013) In vitro antioxidant and antimicrobial activity of some Lamiaceae species. Iranian Journal of Science \& Technology, A1: 1-9.

7. Hanahan, D. \& Weinberg, R.A. (2000) The hallmarks of cancer. Cell, 100: 57-70.

8. Domcke, S., Sinha, R., Levine, D.A., Sander. C., Schultz, N. (2013) Evaluating cell lines as tumour models by comparison of genomic profiles. Nature Communications, 4: 21-26.

9. Ghoncheh M, Pournamdar Z, Salehiniya H,. (2016) Incidence and mortality and epidemiology of breast cancer in the world. Asian Pac J Cancer Prev 2016;17 (S3): 43-46.

10. Sashidhara, K.V.; Avula, S.R.; Sharma, K.; Palnati, G.R.; Bathula, S.R..(2013). Discovery of coumarin monastrol hybrid as potential anti-breast tumor-specific agent. Eur. J. Med. Chem. 2013, 60: 120-127.

11. Afifi U. Fatma, Violet Kasabri, Hala I. Al-Jaber, Barakat E. Abu Irmaileh, Mahmoud A. AL-Qudah and Ismail F. Abaza, (2016) Composition and Biological Activity of Volatile Oil from Salvia judaica and S.multicaulis from Jordan. Natural Product Communications, 11(4): 535538.

12. Abu-Dahab, R., Afifi, F., Kasabri, V., Majdalawi, L., Naffa, R. (2012) Comparison of the anti-proliferative activity of crude ethanol extracts of nine Salvia species grown in Jordan against breast cancer cell line models. Pharmacognosy Magazine, 8(32): 319-324.

13. Böszörményi A, Héthelyi E, Farkas A, Horváth G, Papp N, Lemberkovics E, Szoke E. (2009) Chemical and genetic relationship among sage (Salvia officinalis L.) cultivars and Judaen sage (Salvia judaica Boiss). Journal of Agriculture and Food Chemistry, 57: 4663- 4667.

14. Martina Jakovljevic', Stela Jokic', Maja Molnar, Midhat Jašic', Jurislav Babic', Huska Jukic' and Ines Banjari., (2019) Bioactive Profile of Various S.officinalis L. Preparations. Plants (2019), 8, 55; doi: 10.3390/plants8030055. 
www. mdpi. Com/journal/plants.

15. Nagwa M. Rasmy., Amal A. Hassan., Mervat I. Foda. And Marwa M. El-Moghazy., (2012) Assessment of the Anti-oxidant Activity of Sage (Salvia officinalis L.) Extracts on the Shelf Life of Mayonnaise, World Journal of Dairy\& Food Sciences 7(1): 28-40, 2012.

16. Yuanyuan Jiang, Li Zhang, HP vasantha Rupasinghe., (2021) The anticancer properties of phytochemical extracts from Salvia plants. Halifax, NS, Canada. Botanics: Targets and Therapy 2016:6 25-44 https://www. dovepress.com/ by 77. 44. 198. 252 on 10May-2020.

17. Firuzi O, Miri R, Asadollahi M, Eslami S, Jassbi AR (2013) Cytotoxic, antioxidant and antimicrobial activities and phenolic contents of eleven Salvia species from Iran. Iranian Journal of Pharmaceutical Research 12(4): 801 810.

18. Legault Jean and Pichette André, (2007) Potentiating effect of b-caryophyllene on anti-cancer activity of a-humulene, iso caryophyllene and paclitaxel. JPP 2007, 59: 1643-1647. DOI 10. 1211/jpp. 59.12.0005 ISSN 00223573.

19. Qing, C., Jiang, C., Zhang, S.J., Ding, J. (2001) Induction of apoptosis in human leukemia K-562 and gastric carcinoma SGC-7901 cells by salvicine, a novel anticancer compound. Anticancer Drugs, 12(1): 51-56.

Copyright: $\bigcirc 2021$ Abeer Saleh. This is an open-access article distributed under the terms of the Creative Commons Attribution License, which permits unrestricted use, distribution, and reproduction in anymedium, provided the original author and source are credited. 